\title{
NITROGEN AND POTASSIUM FERTILIZATION ON GROWTH AND PRODUCTION OF STRAWBERRY CROP AND OCCURRENCE OF TWO-SPOTTED SPIDER MITES AND PREDATORY ONES
}

Oliveiros Miranda dos Santos ${ }^{1}$, Adriano Bortolotti da Silva ${ }^{1}$, José Ricardo Mantovani ${ }^{1}$, Paulo Henrique Siqueira Sabino ${ }^{1}$

${ }^{1}$ Universidade de Alfenas (UNIFENAS), Alfenas - MG. E-mail: oliveiros.santos@ifsuldeminas.edu.br, adriano.silva@unifenas.br, jose.mantovani@unifenas.br,phsabino09@gmail.com

\section{ABSTRACT}

The objective of this work was to verify the growth and yield of the strawberry crop, as well as the population of the two-spotted spider mite, Tetranychus urticae (Koch, 1836) (Acari: Tetranychidae) and the predatory mite Phytoseiulus macropilis (Banks) (Acari: Phytoseiidae), as a function of nitrogen and potassium doses. The experimental design was in randomized blocks. The treatments consisted of combinations of nitrogen $(\mathrm{N})$ and potassium $(\mathrm{K})$ applied by fertigation in $\mathrm{kg} \mathrm{ha}^{-1}$ in the form of urea and potassium chloride: $200 \mathrm{~N}$ and $200 \mathrm{~K}_{2} \mathrm{O} ; 200 \mathrm{~N}$ and $400 \mathrm{~K}_{2} \mathrm{O} ; 400 \mathrm{~N}$ and $400 \mathrm{~K}_{2} \mathrm{O} ; 400 \mathrm{~N}$ and $800 \mathrm{~K}_{2} \mathrm{O}$; and a blank control. The predatory mite showed a higher occurrence shortly after the peak population of the spider mite. The combination of $200 \mathrm{~kg} \mathrm{ha}^{-1}$ of $\mathrm{N}$ with $400 \mathrm{~kg} \mathrm{ha}^{-1}$ of $\mathrm{K}_{2} \mathrm{O}$ increased strawberry yield and decreases the incidence of the two-spotted spider mite.

Keywords: Fragaria x ananassa, Tetranychus urticae, Phytoseiulus macropilis

\section{INFLUÊNCIA DAS ADUBAÇÕES NITROGENADA E POTÁSSICA NO CRESCIMENTO E PRODUÇÃO DA CULTURA DO MORANGUEIRO E NA OCORRÊNCIA DE ÁCAROS RAJADOS E PREDADORES}

\section{RESUMO}

Objetivou-se neste trabalho verificar o crescimento e a produtividade da cultura do morangueiro, bem como a população de ácaro-rajado, Tetranychus urticae (Koch, 1836) (Acari: Tetranychidae) e a do ácaro predador Phytoseiulus macropilis (Banks) (Acari: Phytoseiidae) na cultura do morangueiro em função de doses de nitrogênio e potássio. O delineamento experimental utilizado 
foi em blocos ao acaso. Os tratamentos constaram de combinações de nitrogênio $(\mathrm{N})$ e potássio $(\mathrm{K})$ aplicados via fertirrigação em $\mathrm{kg} \mathrm{ha}^{-1}$ na forma de ureia e $\mathrm{KCl}: 200 \mathrm{~N}$ e $200 \mathrm{~K}_{2} \mathrm{O} ; 200 \mathrm{~N}$ e $400 \mathrm{~K}_{2} \mathrm{O} ; 400 \mathrm{~N}$ e $400 \mathrm{~K}_{2} \mathrm{O} ; 400 \mathrm{~N}$ e $800 \mathrm{~K}_{2} \mathrm{O}$; e uma testemunha. O ácaro predador apresentou maior ocorrência logo após o pico populacional do ácaro rajado. A combinação de $200 \mathrm{~kg} \mathrm{ha}^{-1}$ de $\mathrm{N}$ com $400 \mathrm{~kg} \mathrm{ha}^{-1} \mathrm{de} \mathrm{K}_{2} \mathrm{O}$ aumentou a produtividade do morangueiro e diminui a incidência do ácaro rajado.

Palavras-chave: Fragaria x ananassa, Tetranychus urticae, Phytoseiulus macropilis

\section{INTRODUCTION}

The production of strawberry (Fragaria $x$ ananassa Duch), a crop classified as a fruiting herb, is of great economic importance (AMIL-RUIZ et al., 2011). In Brazil, the southern region of Minas Gerais state is the main producer of this plant, which has been commercially successful due to its organoleptic and nutritional characteristics (PEREIRA et al., 2013; ANTUNES et al., 2007).

In the strawberry crop diseases and pests can significantly compromise production. Among the main pests that may cause the greatest injuries and thus damage the crop, the two-spotted spider mite Tetranychus urticae (Koch, 1836) (Acari: Tetranychidae) stands out. It is currently considered the main pest of the strawberry plant (LOPES et al., 2005), and it is widespread across Brazil (MORAES et al., 1992).

The predatory mite Phytoseiulus macropilis (Banks) (Acari: Phytoseiidae) is considered a specialist mite, and its occurrence is directly influenced by the population of the spider mite (FERLA et al., 2007). In the strawberry crop this mite is found preying on populations of the spider mite, and it is thus considered a potential biological control agent (FADINI et al., 2004). Due to its natural occurrence in the strawberry crop, it is important to adopt tactics that might help in maintaining its population, for example using appropriate fertilizer strategies.

The physiological state of the plants in function of their nutrition may also be related to pest attacks. Both excess and lack of nutrients can spoil the plant physiological balance, influencing yield and pest attacks (MARSCHNER, 1995; MICHEREFF FILHO et al., 2008). When supplied in an unbalanced way, nitrogen and potassium can favor the occurrence of pests in a number of crops (CHAU \& HEONG, 2005). In the strawberry crop, these nutrients can alter the population dynamics of harmful mites (CARDOSO et al., 2002); this is the case especially with nitrogen, which may increase the two-spotted spider mite fecundity (DAUGHERTY, 2011). 
Information about the appropriate management of nutrients for the strawberry crop and its response to fertilization are needed in order to understand the relationship between plant nutrition and the population dynamics of pests such as the two-spotted spider mite (RIBEIRO et al., 2012). Therefore, this study aiming at verifying strawberry growth and yield, the population of the two-spotted spider mite, and the population of the predator mite in the strawberry crop, in function of combined fertilization with nitrogen and potassium.

\section{MATERIAL AND METHODS}

The experiment was carried out in field conditions, in strawberry beds protected by an agricultural greenhouse, of the forcing tunnel model, in the county of Inconfidentes, southern Minas Gerais State, Brazil from August to November 2015.

In the experimental area, the soil was classified as a haplic Gleysol, according to Santos et al. (2013), with a surface layer $(0$ to $20 \mathrm{~cm}$ ) that presented routine initial chemical characterization (SILVA, 1999): $\mathrm{pH}$ in $\mathrm{H}_{2} \mathrm{O}=6.0 ; \mathrm{P}-\mathrm{Mehlich}=75 \mathrm{mg} \cdot \mathrm{dm}^{-3} ; \mathrm{K}=64 \mathrm{mg} \cdot \mathrm{dm}^{-3} ; \mathrm{Ca}=5.0 \mathrm{cmol}_{\mathrm{c} .} \mathrm{dm}^{-3} ; \mathrm{Mg}^{-}$ $1.8 \mathrm{cmol}_{\mathrm{c} .} \mathrm{dm}^{-3} ; \mathrm{Al}^{3+}=0.3 \mathrm{cmol}_{\mathrm{c} .} \mathrm{dm}^{-3} ; \mathrm{V}=71 \%$ and organic matter $=31 \mathrm{~g} \cdot \mathrm{dm}^{-3}$.

In the area where the experiment was conducted lime was not applied, because the base saturation $(\mathrm{V} \%)$ of the soil was above that considered appropriate for the crop and fertilization at planting was carried out with an application of $400 \mathrm{~kg} \mathrm{ha}^{-1}$ of $\mathrm{P}_{2} \mathrm{O}_{5}$, in the form of simple superphosphate $\left(18 \%\right.$ de $\mathrm{P}_{2} \mathrm{O}_{5}$ ), across the whole area, followed by incorporation (NANNETTI \& SOUZA, 1999). The rainfall and temperature data during the experimental period are presented (Figure 1).

The design used was in randomized blocks, with five treatments and four repetitions. The treatments were composed of combinations of doses of $\mathrm{N}$ and $\mathrm{K}_{2} \mathrm{O}$, respectively, 200 and 200; 200 and 400; 400 and 400; and 400 and $800 \mathrm{~kg} \mathrm{ha}^{-1}$; and one blank control, which was not fertilized with $\mathrm{N}$ and $\mathrm{K}_{2} \mathrm{O}$. The sources of nutrients used were urea $(45 \%$ of $\mathrm{N})$ and potassium chloride $\left(58 \%\right.$ of $\left.\mathrm{K}_{2} \mathrm{O}\right)$.

Each repetition was arranged in a planting bed of $25 \mathrm{~m}$ in length by $1.50 \mathrm{~m}$ in width. The strawberry cultivar (Fragaria $x$ ananassa Duch.) used was Oso Grande, and the seedlings at the moment of being transplanted presented a length of about $8 \mathrm{~cm}$ and 3 to 4 leaves. Spacing between plants was $0.3 \mathrm{~m}$ and between rows was $0.35 \mathrm{~m}$. The total area of each plot was composed of 3 rows of plants, measuring $4 \mathrm{~m}$ in length, totaling 39 plants, and the useful area of each plot was the central 15 plants. 


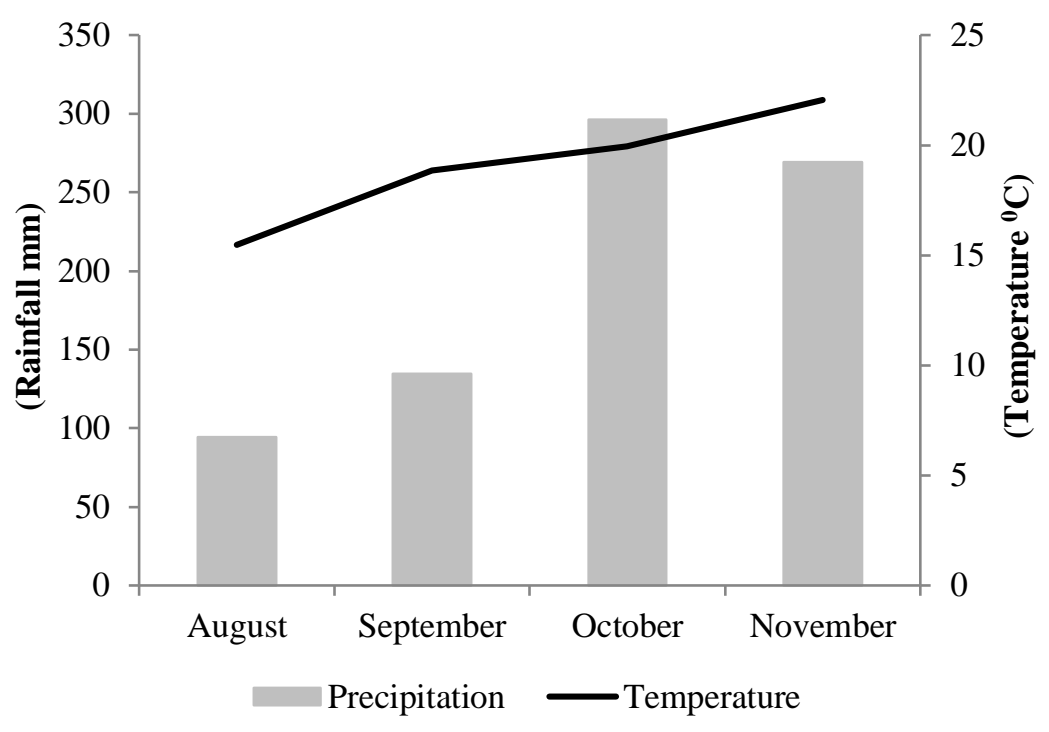

Figure 1. Mean precipitation $(\mathrm{mm})$ and temperature $\left({ }^{\circ} \mathrm{C}\right)$ during the months of August to November, Inconfidentes -MG, 2015.

Fertilization with nitrogen and potassium, in accordance with the treatments, was applied by fertigation, which took place every two days, together with irrigation, throughout the whole crop cycle. The irrigation was carried out throughout the period of the experiment, considering the precipitation and evaporation of water, evaluated in a "class A" tank. Drip irrigation was used, with a space of 0.25 $\mathrm{m}$ between nozzles, a flow of $60 \mathrm{ml}$ minute ${ }^{-1}$, totaling $2.4 \mathrm{~L} \mathrm{hour}^{-1}$ per plot.

Population monitoring of the two-spotted spider mite and of P. macropilis was carried out weekly, from August to November, totaling 16 evaluations. At each evaluation there was a randomized collection of two leaflets per plant in the useful area of the plots. In the laboratory the number of twospotted spider mites and of $P$. macropilis on each leaflet were identified and quantified, with the help of a stereoscopic microscope, at an enlargement of 40x. Twenty six collections were carried out in the useful area of each plot, and evaluations were made of total crop yield, percentage loss of fruit weight, and content of total soluble solids. At the end of the experiment evaluations were made of fresh and dry mass of the above-ground parts and root system of the strawberry plants. 
The results were submitted to analysis of variance (ANOVA), and the means were compared by Scott-Knott test, at 5\% probability, with the help of the statistical program SISVAR (FERREIRA, 2011).

\section{RESULTS AND DISCUSSION}

Fertilization with nitrogen and potassium affected the production of fresh mass of both the aerial part and the root system, and also the yield of the strawberry plants (Tables 1 and 2). The combinations of $200 \mathrm{~N}$ and $200 \mathrm{~K}_{2} \mathrm{O} ; 200 \mathrm{~N}$ and $400 \mathrm{~K}_{2} \mathrm{O}$ and $400 \mathrm{~N}$ and $400 \mathrm{~K}_{2} \mathrm{O} \mathrm{kg} \mathrm{ha}{ }^{-1}$ provided a greater production of fresh mass in the aerial part of the plants in relation to the control treatment. For the production of fresh root mass, the combinations of $200 \mathrm{~N}$ and $400 \mathrm{~K}_{2} \mathrm{O}$, and of $400 \mathrm{~N}$ and $800 \mathrm{~K}_{2} \mathrm{O}$ $\mathrm{kg} \mathrm{ha}^{-1}$ were superior to the others; in relation to the fruit yield the doses of $200 \mathrm{~N}$ and $400 \mathrm{~K}_{2} \mathrm{O} \mathrm{kg} \mathrm{ha}{ }^{-1}$ was the most appropriate. The treatment that received the association of the highest doses of $\mathrm{N}(400 \mathrm{~kg}$ $\left.\mathrm{ha}^{-1}\right)$ and of $\mathrm{K}_{2} \mathrm{O}\left(800 \mathrm{~kg} \mathrm{ha}^{-1}\right)$ presented the lowest production of fresh mass in the aerial part and the lowest yield. The other parameters evaluated - dry mass of the aerial part $\left(33.9 \pm 4.1 \mathrm{~g} \mathrm{plant}^{-1}\right)$ and of the roots $\left(2.8 \pm 0.4\right.$ g plant. $\left.^{-1}\right)$, loss of weight $(15.2 \pm 0.9 \%)$ the content of soluble solids in the fruit $(6 \pm$ $0.5^{\circ}$ Brix $)$ - were not affected by the doses of the nutrients. 
Table 1. Fresh and dry mass of the aerial part and the root system of the strawberry plant in function of fertilization with nitrogen and potassium. Inconfidentes - MG, 2015.

\begin{tabular}{|c|c|c|c|c|}
\hline $\begin{array}{c}\text { Combinations } \\
\mathrm{N}: \mathrm{K}_{2} \mathrm{O}\left(\mathrm{kg} \cdot \mathrm{ha}^{-1}\right)\end{array}$ & $\begin{array}{c}\text { FMAP } \\
\left(\text { g plant }^{-1}\right)\end{array}$ & $\begin{array}{c}\text { FMRS } \\
\left(\text { g plant }^{-1}\right)\end{array}$ & $\begin{array}{c}\text { DMAP } \\
\left(\text { g plant }^{-1}\right)\end{array}$ & $\begin{array}{c}\text { DMRS } \\
\left(\text { g plant }^{-1}\right)\end{array}$ \\
\hline $200: 200$ & $126.50 \mathrm{~A}$ & $13.25 \mathrm{~B}$ & $32.00 \mathrm{~A}$ & $3.00 \mathrm{~A}$ \\
\hline 200: 400 & $131.00 \mathrm{~A}$ & $16.50 \mathrm{~A}$ & $39.25 \mathrm{~A}$ & $3.25 \mathrm{~A}$ \\
\hline 400: 400 & $132.75 \mathrm{~A}$ & $13.25 \mathrm{~B}$ & $34.75 \mathrm{~A}$ & $2.75 \mathrm{~A}$ \\
\hline 400: 800 & $90.25 \mathrm{C}$ & $15.00 \mathrm{~A}$ & $28.25 \mathrm{~A}$ & $2.75 \mathrm{~A}$ \\
\hline Control & $105.75 \mathrm{~B}$ & $10.75 \mathrm{C}$ & $35.25 \mathrm{~A}$ & $2.25 \mathrm{~A}$ \\
\hline $\mathrm{CV}(\%)$ & 14.23 & 16.50 & 18.14 & 20.10 \\
\hline
\end{tabular}

FMAP - fresh mass of aerial part; FMRS - fresh mass of root system; DMAP - dry mass of aerial part; DMRS - dry mass of root system.

Means followed by the same letter in the column do not differ from one another by Scott-Knott test ( $>>0.05)$.

Table 2. Yield of strawberry plant, loss of weight and content of total soluble solids in the strawberry fruit in function of fertilization with nitrogen and potassium. Inconfidentes - MG, 2015.

\begin{tabular}{|c|c|c|c|}
\hline $\begin{array}{c}\text { Combinations } \\
\mathrm{N}: \mathrm{K}_{2} \mathrm{O}\left({\left.\mathrm{kg} . \mathrm{ha}^{-1}\right)}^{-1}\right.\end{array}$ & YSP (t ha-1) & FWL (\%) & TSS ( ${ }^{\circ}$ BRIX) \\
\hline $200: 200$ & $37.25 \mathrm{~B}$ & $13.80 \mathrm{~A}$ & $6.00 \mathrm{~A}$ \\
\hline 200: 400 & $45.97 \mathrm{~A}$ & $14.99 \mathrm{~A}$ & $5.50 \mathrm{~A}$ \\
\hline 400: 400 & $36.05 \mathrm{~B}$ & $16.06 \mathrm{~A}$ & $5.75 \mathrm{~A}$ \\
\hline 400: 800 & $25.12 \mathrm{C}$ & $16.11 \mathrm{~A}$ & $6.75 \mathrm{~A}$ \\
\hline Control & $32.95 \mathrm{~B}$ & $15.25 \mathrm{~A}$ & $6.00 \mathrm{~A}$ \\
\hline $\mathrm{CV}(\%)$ & 20.64 & 15.25 & 17.01 \\
\hline
\end{tabular}

YSP - yield of strawberry plant; FWL - fruit weight loss; TSS - total soluble solids in fruit. Means followed by the same letter in the column do not differ from one another by Scott-Knott test ( $\mathrm{p}>0.05)$.

Ribeiro et al. (2012) did not verify an effect of fertilization with nitrogen and potassium, via fertigation, on the total and commercial production of strawberry plants, in the number of fruits per plant and in the mean weight of fruit. Souza et al. (2014) observed that fertilization with potassium, in fertigation, increased the production of dry mass in the aerial and root parts of the strawberry plant, cultivar Oso Grande, but it reduced yield, the number and weight of fruits per plant, possibly because of the saline index of the fertilizer. Fischer et al. (2015) affirmed that the doses of 20;26.6; 33.3 and 
$40 \mathrm{~kg} \cdot \mathrm{ha}^{-1}$ of $\mathrm{N}$ applied at planting, associated with the application of $180 \mathrm{~kg}^{-\mathrm{ha}^{-1}}$ of $\mathrm{N}$ as dressing, did not affect the production of the four cultivars of strawberry, including the cultivar Oso Grande.

There was an effect $(p<0.05)$ of fertilization with nitrogen and potassium on the populations of two-spotted spider mite (Table 3). However, for the population of P. macropilis no significant effect of the treatments was noted, and the mean value of the population was $9.74 \pm 1.6$ individuals per leaflet.

The largest population of the two-spotted spider mite was found in the control treatments (218 individuals per leaflet) and in the treatment with $400 \mathrm{~kg} \cdot \mathrm{ha}^{-1}$ of $\mathrm{N}$ and $800 \mathrm{~kg} \cdot \mathrm{ha}^{-1}$ of $\mathrm{K}_{2} \mathrm{O}(180.75$ individuals per leaflet) (Table 3). For the other combinations there was a lower occurrence of this mite.

Table 3 - Mean population of Phytoseiulus macropilis and two-spotted spider mite on strawberry plants in function of fertilization with nitrogen and potassium. Inconfidentes - MG, 2015.

\begin{tabular}{ccc}
\hline $\begin{array}{c}\text { Combinations } \\
\mathbf{N}: \mathbf{K}_{\mathbf{2}} \mathbf{O}\left(\mathbf{k g . h a}^{-\mathbf{1}}\right)\end{array}$ & $\begin{array}{c}\text { Phytoseiulus } \\
\text { macropilis }\end{array}$ & Tetranychus urticae \\
\hline $200: 200$ & $8.75 \mathrm{~A}$ & $93.30 \mathrm{~A}$ \\
$200: 400$ & $10.31 \mathrm{~A}$ & $74.36 \mathrm{~A}$ \\
$400: 400$ & $11.87 \mathrm{~A}$ & $51.94 \mathrm{~A}$ \\
$400: 800$ & $7.68 \mathrm{~A}$ & $180.75 \mathrm{~B}$ \\
Control & $10.12 \mathrm{~A}$ & $218.00 \mathrm{~B}$ \\
\hline $\mathrm{CV}(\%)$ & 45.61 & 62.22 \\
\hline
\end{tabular}

Means followed by the same letter in the column do not differ from one another by the Scott-Knott test ( $p>0.05)$. 


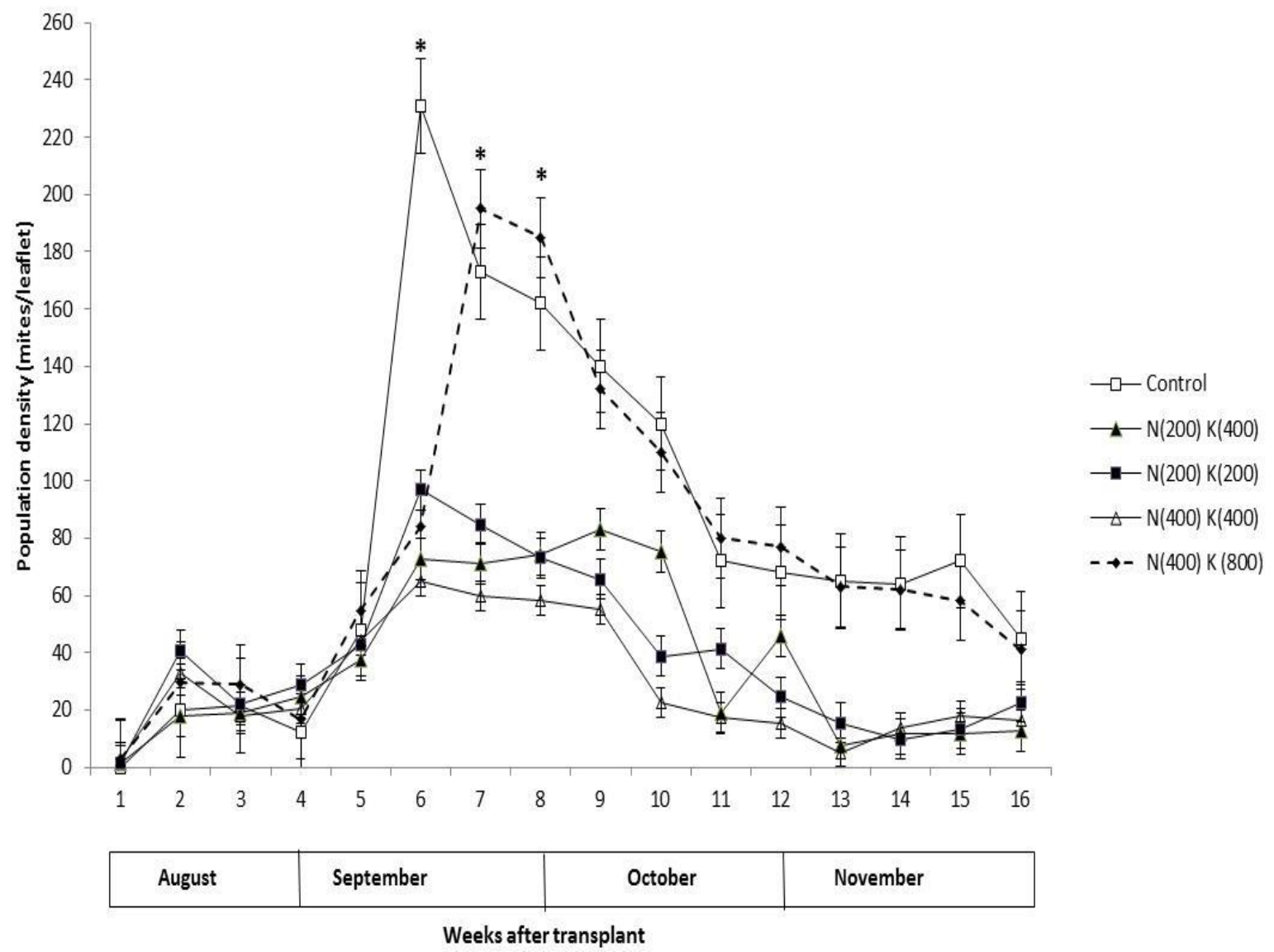

Figure 2. Fluctuation in the population of two-spotted spider mite on strawberry plants, cultivar Oso Grande, submitted to fertigation with different ratios of $\mathrm{N}$ and $\mathrm{K}$. Evaluations carried out between August and November; means $( \pm$ SD) followed by an asterisk are significantly different for that period of sampling, by Scott-Knott test, as 5\% probability. Inconfidentes - MG, 2015

The increase in the population of the two-spotted spider mite observed in the treatment with the greatest dose of the $\mathrm{N}$ and $\mathrm{K}$ combination is correlated with the lowest strawberry production, which probably occurred due to the imbalance in nutrients (MALAVOLTA et al., 1997), leaving the plants more susceptible to pests. Additionally, nitrogen in high concentrations makes the plant tissue tenderer and increases the concentration of free amino acids in the apoplast and on the cell surface, which favors a higher incidence of insects (BARROS et al., 2007). According to Daugherty (2011), high nitrogen content boosts the reproduction and fecundity of the two-spotted spider mite, thus increasing its population in productive areas. 


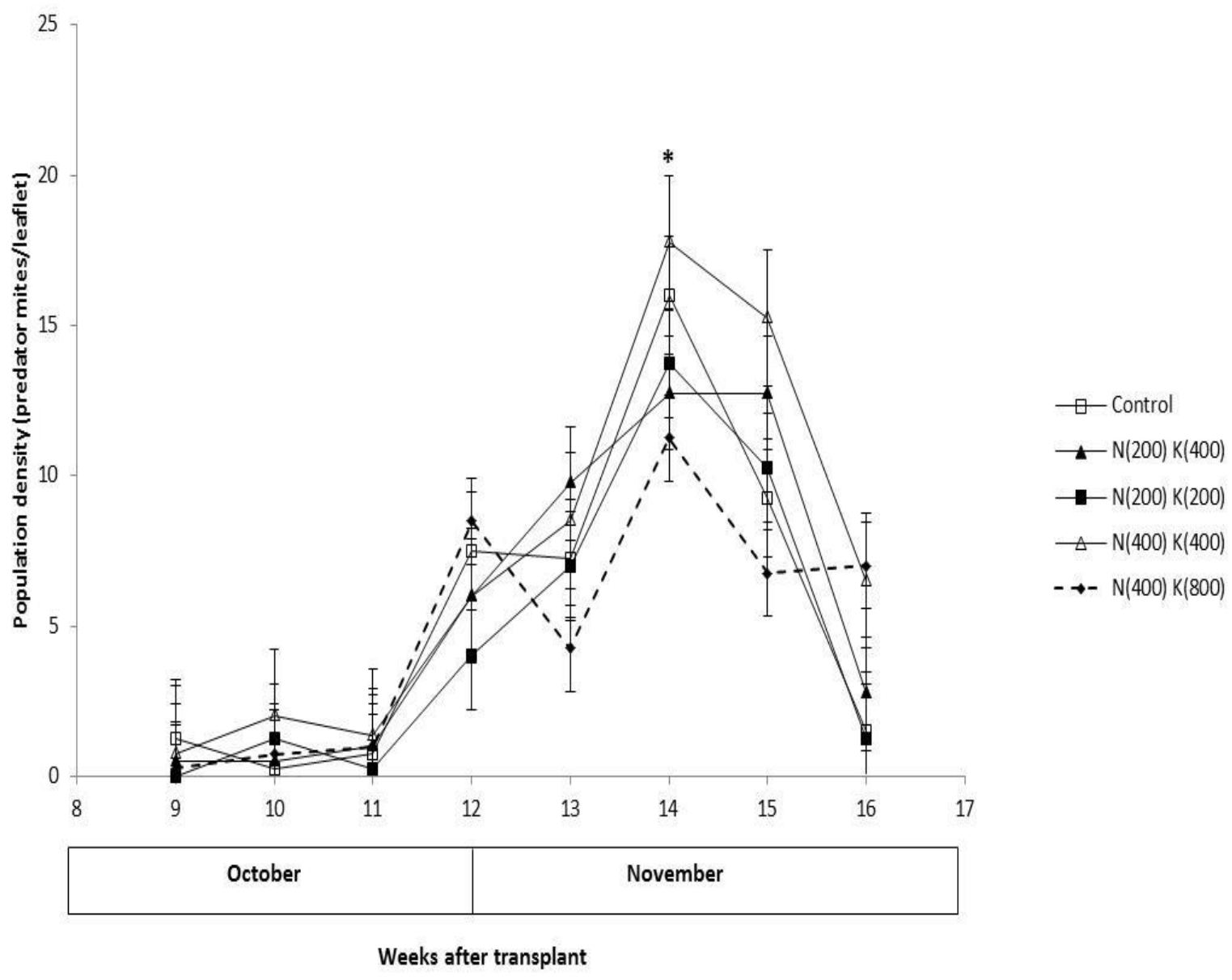

Figure 3. Population fluctuation of Phytoseiulus macropilis on strawberry plants, cultivar Oso Grande, submitted to fertigation with different ratios of $\mathrm{N}$ and $\mathrm{K}$. Evaluations carried out between August and November; means $( \pm \mathrm{SD})$ followed by an asterisk are significantly different for that sampling period, by Scott-Knott test, at 5\% probability. Inconfidentes - MG, 2015.

In relation to potassium, as it participates in the assimilation of nitrogen by plants, its deficiency or excess provokes an accumulation of soluble amino acids, which are nutrients for the pests. Furthermore, cell turgor can be lost under these conditions, and this may become a physical factor that makes pest attacks easier (YAMADA, 2004).

Various studies have already been carried out to evaluate the effect of fertilization on the population of mites and aphids, and the results have been contrasting. Michereff Filho et al. (2008) affirmed that different levels of fertilization with $\mathrm{N}$ and $\mathrm{K}$, via fertigation, did not affect the infestation and the severity of the damage done by the mite Aceria guerreronis (KEIFER) (Acari: Eriophyidae), on coconut. Najafabadi et al. (2011) verified an increase in the population of the two-spotted spider mite with an increase of doses of nitrogen in bean plants. Mohiseni et al. (2011) verified that the population 
density of the two-spotted spider mite was significantly less in plants that received high proportions of $\mathrm{K}$ in relation to $\mathrm{N}$ on bean plants. Ribeiro et al. (2012) noted that alterations in the ratios between $\mathrm{N}$ and $\mathrm{K}$ in the management of fertilizers did not efficiently control the two-spotted spider mite on strawberry plants. However, these authors observed that nitrogen fertilization increased the population density of the two-spotted spider mite, while potassium fertilization had a negative effect on the population dynamics of this strawberry pest.

The peak in the two-spotted spider mite population, in all treatments, took place in the month of September, when the precipitation was low and the temperature started to increase, which is in agreement with data reported by Lopes et al. (2005), who observed greater populations of two-spotted spider mites in the months of August and September. From October, with the start of the wet season, the population of this pest decreased (Figure 2). An increase in the two-spotted spider mite population on strawberry plants in the period with lower precipitation and the absence of predators, both of which are factors that make controlling this pest difficult, were also reported by Fadini et al. (2004).

In relation to the predatory mites, the occurrence was detected from October, and the population peak was observed in the second week of November (Figure 3). This may possibly have happened due to the higher incidence of the two-spotted spider mite in September, which provided a food source for the predator mite and may have led to an increase of its population. After this peak there was a reduction in the predator mite in the fourth week of November, probably due to a lack of the twospotted spider mite. The mite $P$. macropilis is a specialist as regards its eating habit, exclusively consuming mites belonging to the genus Tetranychus. The specialist mites reproduce more quickly than the generalists when food availability is high. When the population density of the two-spotted spider mite is low, P. macropilis normally disperses outside the cultivated area in search of more food (MCMURTRY \& CROFT, 1997). It should be noted that during the experiment no chemical agent to kill mites was used.

The highest dose of fertilizer promotes a fall in yield and an increase in the two-spotted spider mite population; the population of P. macropilis accompanies the growth of the two-spotted spider mite population. Balanced fertilization in the strawberry crop is an important tool for the appropriate development and productivity of the crop, as well as directly influencing population peaks of pest and predator mites. 


\section{CONCLUSIONS}

The combination of $200 \mathrm{~N}$ and $200 \mathrm{~K}_{2} \mathrm{O} ; 200$ and $400 \mathrm{~K}_{2} \mathrm{O}$ and $400 \mathrm{~N}$ and $400 \mathrm{~K}_{2} \mathrm{O}$ kg.ha' ${ }^{-1}$ in fertigation reduced the incidence of the two-spotted spider mite. The population of $P$. macropilis accompanied the population growth of the two-spotted spider mite and the combined dose of $200 \mathrm{~N}$ and $400 \mathrm{~K}_{2} \mathrm{O} \mathrm{kg.ha}{ }^{-1}$ presented the highest yield for the strawberry plant.

\section{ACKNOWLEDGEMENTS}

To FAPEMIG (Fundação de Amparo a Pesquisa do Estado de Minas Gerais) for support.

\section{REFERENCES}

AMIL-RUIZ, F.; BLANCO-PORTALES, R.; MUÑOES-BLANCO, J.; CABALLEO, J.L. 2011. The strawberry plant defense mechanism: A molecular review. Plant cell physiology, Oxford v.52, n. 11, p. 1873-1903.

ANTUNES, L.E.C.; REISSER JÚNIOR, C. 2007. Fragole, i prodottori brasiliani mirano all'esportazione in Europa. Frutticoltura, Milão v.69, n.5, p. 60-65.

BARROS, R.; DEGRADE, P.E.; FERNANDES, M.G.; NOUEIRA, R.F. 2007. Efeito da adubação nitrogenada em algodoeiro sobre a biologia de Aphis gossypii Glöver (Hemiptera: Aphididae). Neotropical Entomology, Londrina v. 36, n.5, p. 752-758.

CARDOSO, A. M.; CIVIDANES, F. J.; NATALE, W. 2002. Influência da adubação fosfatadapotássica na ocorrência de pragas na cultura da soja. Anais da Sociedade Entomológica do Brasil, Londrina v. 31, n.3, p. 441-444.

CHAU, L. M.; HEONG, K. L. 2005. Effects of organic fertilizers on insect pest and diseases of rice. Omonrice Journal, Saigon v. 13, p. 26-33.

DAUGHERTY M.P. 2011. Host plant quality, spatial heterogeneity, and the stability of mite predatorprey dynamics. Experimental and Applied Acarology Amsterdam 53, n.2, 311-322.

FADINI, M.A.M.; VENZON, M.; PALLINI, A.; OLIVEIRA, H. 2004. Manejo ecológico de ácaros fitófagos na cultura do morangueiro. In: Simpósio Nacional do Morango, Pelotas. Anais: Embrapa, p. 79-100.

FERLA, N.J.; MARCHETTI, M.M.; GONÇALVES, D. 2007. Ácaros predadores (Acari) associados à cultura do morango (Fragaria sp., Rosaceae) e plantas próximas no Estado do Rio Grande do Sul. Biota Neotropica, São Paulo v. 7, n.2, p. 103-110.

FERREIRA, D.F. 2011. Sisvar: A computer statistical analysis system. Ciência e Agrotecnologia, Lavras v. 35, n. 6, p. 1039-42.

FISCHER, I.H.; FERNANDES JUNIOR, F.; KANO, C.; DONADELLI, A.; PALHARINI, M.C.A. 2015. Adubação nitrogenada sobre a ocorrência de doenças em pós-colheita do morango. Arquivo do Instituto Biológico Campinas v. 82, p. 1-5.

LOPES, H.; SILVA, B.C.; NASCIMENTO, E.F.; RAMOS, L.X.; PEREIRA, M.; CARNEIRO RG. 2005. A cultura do morangueiro no Distrito Federal. Brasilia, DF: EMATER. 76p.

MALAVOLTA, E.; VITTI, G.C.; OLIVEIRA, S.A. 1997. Avaliação do estado nutricional de plantas: Princípios e aplicações. Piracicaba: POTAFOS, 319p. 
MARSCHNER, H. 1995. Mineral nutrition of higher plants, New York: Academic Press, $2^{\text {a }}$ ed. 889 p.

MCMURTRY, J.A.; CROFT, B.A. 1997. Life-styles of Phytoseiidae mites and their roles in biological control. Annual Review of Entomology, California v.42, p. 291-321.

MICHEREFF FILHO, M.; SOBRAL, L.F.; FEREIRA, J.M.S.; RODRIGUES, A.R.S.; MICHEREFF, M.F.F. 2008. Adubação química, ataque do ácaro Aceria guerreronis e produtividade do coqueiro 'Anão-Verde'. Pesquisa Agropecuária Brasileira, Brasília v. 43, n.3, p. 303-308.

MOHISENI, A.; DASHADI, M.; SHAHVERDI, M.; KOOHKI, MH. 2011. Effect of macroelements (NPK) in the control of Tetranychus urticae Koch (Acari: Prostigmata: Tetranychidae) on Derakhshan bean cultivar and its agronomic characteristics. Journal of Plant Protection, Mashhad v. 25, n.2, p.107-115.

MORAES, G.J. 1992. Perspectivas para o uso de predadores no controle de ácaros fitófagos no Brasil. Pesquisa Agropecuária Brasileira, Brasília v.27, p.263-270.

NAJAFABADI, S.S.M.; SHOUSHTARI, R.V.; ZAMANI, A.; ARBAD, M.; FARAZMAND, H. 2011. Effect of nitrogen fertilization on Tetranychus urticae Koch (Acari: Tetranychidae) populations on common bean cultivars. American-Eurasian Journal of Agriculture, Dubai v.11, n.4, p. 568576.

NANNETTI, D.C.; SOUZA, R.J. 1999. Sugestão de adubação para o morango. In: RIBEIRO, A.C.; GUIMARÃES, P.T.G.; ALVAREZ V, V.H. (ED). 5º aproximação. Viçosa, MG, p. 198-199.

PEREIRA, R.B.; PINHEIRO, J.B.; CARVALHO, A.D.F. 2013. Diagnose e controle alternativo de doenças em tomate, pimentão, cucurbitáceas e cenoura. Brasília, DF: Embrapa Hortaliças, 16p.

RIBEIRO, M.G.P.M.; MICHERFF FILHO, M.; GUEDES, I.M.R.; JUNQUEIRA, A.M.R. 2012. Efeito da adubação química na infestação do ácaro rajado e na produção do morangueiro. Horticultura Brasileira, Vitória da Conquista v.30, n.4, p. 673: 680.

SANTOS H.G.; JACOMINE, P.K.T.; ANJOS, L.H.C; OLIVEIRA, V.A.; OLIVEIRA, J.B.; COELHO, M.R.; LUMBRERAS, J.F.; CUNHA, T.J.F. 2013. Sistema Brasileiro de Classificação do Solo. 3.ed.rev.ampl. Brasília: Embrapa Solos, 353p.

SHANKS JUNIOR, C.H, MORRE, P.P. 1995. Resistence to twospotted spider mite and strawberry aphid in Fragaria chiloensis, F. virginiana, and F. $x$ ananassa clones. HortScience, Virginia v. 30, n.3, p. 596: 599.

SILVA, F.C. 1999. Manual de análises químicas de solos, plantas e fertilizantes. Brasília: Embrapa, 370p.

SOUSA, G.G.; VIANA, T.V.A.; PEREIRA, E.D.; ALBUQUERQUE, A.H.P.; MARINHO, A.B.; AZEVEDO, B.M. 2014. Fertirrigação potássica na cultura do morango no litoral Cearense. Bragantia, Campinas v. 73, n. 1, p.1-6.

WARING, G.; COBB, N. S. 1992. The impact of plant stress on herbivore population dynamics. In: BERNAYS, E. (Ed.) Insect-plant interactions. London: CRC, v. 4, p. 167-226.

YAMADA, T. 2004. Resistência de plantas às pragas e doenças: pode ser afetada pelo manejo da cultura. Informações Agronômicas, Piracicaba: Potafós, 24p. 